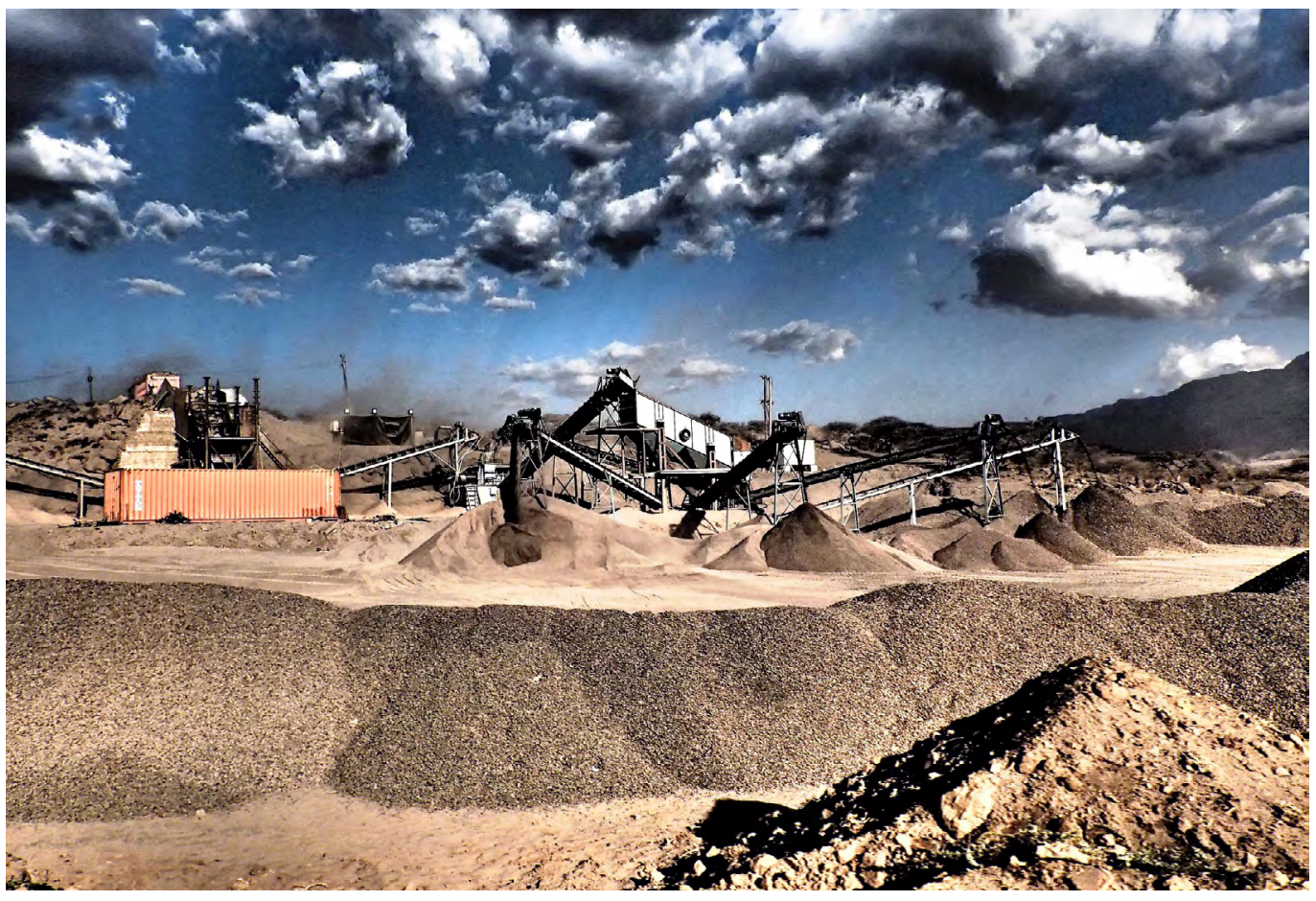

\section{Africa Drifters}

Miriam DRIESSEN
Gravel Pit, Chinese

Construction Site, Ethiopia PC: Jasmine Halki.
Increased mobility from China to Africa over the past two decades has given birth to the 'Africa drifter' (非漂). Employed and driven, yet restless and plagued by the lack of a sense of security, many Chinese who move to Africa for work, especially those attached to large-scale infrastructure projects, find themselves afloatcaught between remaining and returning. Why do Africa drifters wind up in this uncertain state? And how can we link this type of mobility to developments in China?

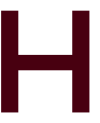
ui (a pseudonym) was searching for emeralds when I first met him in 2017. On the side, he managed construction work on a road project in the homeland of the Nyangatom in southern Ethiopia. Short-tempered but generous, Hui was always bustling onsite, shouting orders, or waving directions when it was too noisy for his voice to carry. Now and then he called local labourers to the side to split stones.

Unable to look to his parents for financial support to get ahead in life, Hui had left China after graduating from college in 2010. He had joined a Chinese state-owned enterprise, lured by the promise of good pay. After five long years in Ethiopia, he returned to China and married. He decided to stay. 
Hui's newly established business in China was, however, short-lived. He had taken a subcontract on a real estate project in his home province, Shaanxi. The contractor owed him more than one million yuan when the project was halted. Pressed to repay his debts and provide for his family, Hui left for Africa again.

Back in Ethiopia, he became restless. His salary was not quite enough. Only a fortune in gemstones, he believed, could help him craft a respectable life in China.

\section{Afloat}

Hui is one of the many feipiao (非漂, 'Africa drifters') who work on Chinese-run construction projects across Africa. His story is at once unique and illustrative of a large group of Chinese men-certified engineers and weathered builders alike-who seek to create a better life for themselves and their families in China by moving overseas. They hope to generate stability through mobility.

Following four decades of unprecedented migration from the countryside to the cities and beyond, governed by state policies that regulate and restrict settlement, mobility has become the norm in present-day China. For feipiao, mobility is a means to craft a fulfilling future and stake a claim to social presence in a rapidly developing society at home. Yet, why do Africa drifters, as Hui's story illustrates, continue to move? How can we define piao (漂 or 飘) mobility and explain its prevalence?

Chinese mobility to Africa gained pace in the early 2000s. It was facilitated by state-owned enterprises, which, prompted by Jiang Zemin's 'Going Out Policy' (走出去战略), had started participating in international tenders for infrastructure projects across Africa, initially funded by the International Development Association and other, mostly Western, donors. The threshold for migration was low. Chinese companies provided and arranged everything, including flights, housing, meals, and medication. The majority of workers who joined this wave of migration were men, chiefly from rural backgrounds. They were first-generation peasant workers or their sons, like Hui, who was the first in his family to earn a college degree. Since the late 2000s, the Chinese Government and its development banks have started funding more and more projects, while domestic construction firms have expanded. Chinese activities in Ethiopia diversified into trade, hospitality, agriculture, and manufacturing. While some Chinese traders and entrepreneurs embrace a settler mentality (Lin 2014), the majority of Chinese engineers and builders attached to large-scale construction projects still view their stay in Africa as temporary. They hope to return to China.

\section{The Birth of Drifting}

The feipiao have grown out of a particular historical configuration, as have their predecessors and contemporaries, the beipiao (北漂, 'Beijing drifters'). The character 漂 describes a certain form of mobility-one that is constant, repetitive, and lacks clear direction (Zhou 2006: 55). The beipiao grew out of mass migration from the countryside to Beijing, combined with concerted efforts by the state to govern mobility (Zhang 2018). Those who were lured to the city found only a temporary home. Beipiao, much like their counterparts in other cities and regions across China, such as the shangpiao (上漂, 'Shanghai drifters') and the nanpiao (南漂, 'southern drifters'), remained outsiders (Yang et al. 2016).

What characterises drifters in China, and distinguishes them from their settled counterparts, is their lack of a local hukou (户口, 'household registration'), and the social security and sense of belonging attached to it. Their identity derives from not being or not belonging, trapping them in constant movement. They move from one place to 
another, one job to another, and one opportunity to another, in an attempt to satisfy a longing for stability. Through their hypermobility, drifters at once transgress and submit to government mobility regimes. Indeed, many beipiao readily acknowledge that Beijing will never become their home.

Described as a generation (漂一代) or a social group (漂一族), Beijing drifters and Africa drifters are the children of their time. They are carried along by social currents set in motion by rapid development in China. Feipiao often mentioned a lack of agency or control. This is not to say that drifting is not attractive; it signifies freedom and can be exhilarating. In China, however, 'drifting' (漂泊) carries a negative connotation, describing the movement of the restless and the rootless (Hunt 2016).

\section{From Beipiao to Feipiao}

'From a beipiao I have become a feipiao', a Chinese purchaser in Ethiopia noted after he ended a phone call with his wife in the documentary China in Ethiopia (Zhou 2018). When life in Beijing no longer offered sufficient opportunities, Africa gave hope. A shifting migration frontier has brought domestic ruralurban migrants to destinations further afieldin Southeast Asia, Africa, South America, and beyond.

Whereas beipiao came of age in an era of rapid economic development, feipiao were born of a decade of slow growth and overcapacity, which has generated a spillover of not only commodities and technology, but also human resources. A competitive job market, skyrocketing house prices, and rising living costs in urban China push drifters further afield in search of better opportunities. Mobility has evolved into hypermobility.

Much like beipiao, feipiao remain on the move. In Africa, they are mere passers-by. The point of reference continues to be China, at least for many. However, the very circumstances that drive feipiao to Africa pose a challenge for their return.

\section{Social Tides}

One reason feipiao are caught between remaining and returning is the expectation of upward social mobility created by four decades of economic growth in mainland China. Even if they cannot change their own lives, feipiao hope to improve the lives of significant others, such as their sons. 'If I would have a girl, I would not need to come here,' Bo (a pseudonym), a mechanic working for a Chinese stateowned company, admitted. Bo had relocated to Ethiopia at the start of 2020 for the sake of his four-year-old son. 'I want to create a better life for my son, and have him enter a better social circle.' Bo himself was born into a peasant family in Heilongjiang province.

Even though social strata in China are solidifying, the pressure for upward social mobility persists. The main reason for his move to Ethiopia is what Bo calls China's 'circle culture' (圈子文化), which forces people to compare themselves with others and compels them to improve their lives at all costs. 'We Chinese indulge in comparing oneself with others,' he explained to me, blaming the Chinese obsession with saving face (or mianzi, 面子) and, ultimately, Confucius, for what he deemed to be a fatal habit. 'In Ethiopia, it does not matter if you drive a shabby car or a good car, as long as you reach your destination with it,' Bo explained. 'In China, what matters most is the car you drive. Whether you drive a car worth 10,000 yuan or one worth 100,000 yuan makes all the difference.'

Apart from being pushed around by relentless tides, drifters suffer from a lingering sense of insecurity. Boasting college degrees, beipiao used to distinguish themselves from peasant workers along class lines. Echoing a renewed recognition of precarity across social strata in China, feipiao tend to downplay their status, 
typically calling themselves 'peasant workers' (农民工) or 'odd-jobbers' (打工人). A certified engineer in Ethiopia once referred to himself and his colleagues as 'we, China's low-end population' (低端人口) when he relayed to me his colleagues' fears of being unable to return to China, referring to the notion that gained currency after Beijing's infamous eviction of migrants in 2017 ( $\mathrm{Li}$ et al. 2018). 'As long as we do not have a sense of security, we do not belong to the middle class,' he asserted. In fact, he and many of his coworkers earn what could easily be counted as a middle-class income.

Popular narratives and academic studies have sought to define China's middle class in terms of salary, profession, and consumption patterns (Goodman and Chen 2013). For this engineer, belonging to the middle class was determined not by annual income, but by something much less tangible: a sense of security. As the predicaments of Hui and Bo suggest, this sense of security is intimately linked to the wellbeing of one's family. The lack of this ever so hard to obtain feeling made them poor men, who had no option but to continue drifting.

\section{The Question of Return}

'Going back to China equals losing your job,' one engineer claimed. He explained why many feipiao are reluctant to return, whispering: 'Those who tell you they will go back to China are lying.' Returnees may face a period of unemployment or are forced to compromise on a salary that is not quite enough to maintain the middle-class lifestyle they obtained by moving to Ethiopia.

I met Bin (a pseudonym), a talented young engineer, in Addis Ababa on the day he returned from his annual vacation in China in 2019. He admitted, somewhat melancholically, feeling 'disappointed' (失落). 'I have been discarded,' he concluded with a wry smile. His friends in China, he explained, belonged to three groups. Some worked in the start-up sector, others as salaried employees of big companies, such as
Huawei. Only the third group, who still worked unstable and poorly paid jobs, had not yet surpassed him in terms of salary.

Bin had moved to Africa to relieve his family of the debts they incurred for his mother's cancer treatment. He grew up in rural Henan. He excelled in school, and later at university, but had to let go of his dream to continue his education. Since leaving for Ethiopia, Bin had been on the move. He hoped to catch up with society at home and move back. Meanwhile, his feeling of lagging behind was growing stronger.

COVID-19 has made return even more challenging. Many Chinese enterprises have curtailed the mobility of employees and postponed annual vacations to China. Flights are hard to get and prohibitively expensive. As doom scenarios of COVID-19's impact on Africa are being disproved, anxiety is subsiding. The feeling of being discarded from a society that is leaving them behind, however, remains pertinent. 
This text is taken from Made in China Journal: Volume 5, Issue 3, 2020, edited by Ivan Franceschini and Nicholas Loubere, published 2021 by ANU Press, The Australian National University, Canberra, Australia.

doi.org/10.22459/MIC.05.03.2020.05 